\title{
Coconut Oil Extraction from Coconut Milk Press-Cake ${ }^{1}$
}

\author{
L. E. Cancel, J. A. Rosario-Hernández, and E. R. de Hernández ${ }^{2}$
}

\begin{abstract}
Continuous and batch-type extractions of coconut oil were made from coconut milk press-cake. The effect of particle size, solvent flow, and temperature was studied with hexane as the solvent. Particle size was one of the most important factors affecting the efficiency of continuous extraction. Residual oil in experiments with milled press-cake was about $0.8 \%$ while it was about $8.0 \%$ with un milled press-cake. Temperatures of $30^{\circ}, 35^{\circ}$, and $45^{\circ} \mathrm{C}$ left a residue with $2.8,1.3$, and $1.0 \%$ oil, respectively. Batch-type extraction studies showed that a holding time (stirring) of 5 min, a ratio of $4: 1$ ( $\mathrm{ml}$ solvent: $\mathrm{g}$ of press-cake), and a temperature of $25^{\circ}$ $\mathrm{C}$ were the best conditions for this type of extraction.
\end{abstract}

\section{INTRODUCTION AND REVIEW OF LITERATURE}

Coconut press-cake is a byproduct of coconut milk manufacturing. The amount produced is about 40 to $45 \%$ of the original coconut pulp processed $(1,2)$. Fat content of this material varies from 55 to $65 \%$ depending on the process used in coconut milk extraction and the raw material used, whether fresh or frozen (3). In industrial practice, where a continuous screw-press is used for separating the milk, the resulting press-cake is about $41 \%$ of the pulp used and comes out with about $50 \%$ water and $48 \%$ fat (dry basis).

At present coconut press-cake is used as hog feed. However, increased prices of vegetable oils and the present high volume of coconut milk production may justify the industrial extraction of oil from press-cake. Therefore, it was decided to investigate the feasibility of extracting the oil from press-cake.

Coconut oil is largely used in the manufacture of vegetable margarines and shortenings (4) as well as in cosmetics. It is marketed in four grades: prime crude, off-crude, refined, and refined and deodorized. It is commercially extracted from copra by pressing, but more advanced processes are used at present to obtain a high-grade product.

${ }^{1}$ Manuscript submitted to Editorial Board June 20, 1975.

${ }^{2}$ Food Scientist, Research Assistant, and Assistant Food Scientist, respectively, Food Technology Laboratory, Agricultural Experiment Station, Mayagüez Campus, University of Puerto Rico, Río Piedras, P.R. 
Choice of the extraction process for oil seeds depends primarily on the oil content of the seed and the allowable protein denaturation during preparation for extraction. Seeds with oil content up to $30 \%$ may be extracted directly in percolation extractors (8). Oil from seeds with higher oil content can be extracted by an immersion process such as centrifuge battery, or the seeds can be prepressed before the percolation extraction (6).

A number of factors affect the percolation system (7). Particle size of solid material influences the rate of extraction. The smaller the size, the greater the interfacial area between solid and liquid and, therefore, the greater the rate of transfer of solids. The surface may not be so effectively used with a very fine material if circulation of the liquid is impeded.

The liquid chosen as solvent should have a sufficiently low viscosity to circulate freely. The organic lipophilic solvent used most for this process, where the end products are for human food or for feed, is a low molecular weight hydrocarbon such as hexane. It is an excellent solvent for triglycerides and other lipids and is low in cost. Hexane is so effective that it is not likely to be replaced by another solvent when the defatted meal or oil is intended for use as human food or by the animal feed industry (5).

In most cases the solubility of the material which is being extracted will increase with temperature to give a higher extraction rate. Furthermore, the diffusion coefficient will be expected to increase with the rise in temperature and thus improve the rate.

Agitation of the solvent is important because it increases the eddy diffusion, and therefore, increases the transfer of material from the surface of the particle to the bulk of the solution.

The physical and chemical characteristics of the coconut press-cake determine the industrial process required for efficient oil extraction. The current investigation was conducted with the objective of obtaining information that would be needed for development of a plant to extract coconut oil from press-cake.

\section{MATERIALS AND METHODS}

The hexane used as solvent was practical grade, suggested for most laboratory syntheses, with a boiling point of $66^{\circ}$ to $69^{\circ} \mathrm{C}$.

Coconut press-cake is the residue obtained from coconut milk extraction. The press-cake used was obtained from frozen coconut pulp which was later comminuted in a hammer mill with a $\# 3$ screen $(36,0.32-\mathrm{cm}$ diameter perforations per $6.45 \mathrm{~cm}^{2}$ ) and pressed in a hydraulic press by the rack and cloth method to a pressure of $13.01 \mathrm{~kg} / \mathrm{cm}^{2}$. Press-cake was dried in a tray dryer with forced circulation to about $1 \%$ water. Dried cake was characterized according to particle size using U.S. Standard Sieves. For one phase of the study the dried cake was milled in a 
laboratory mill, as suggested by the U.S. Bureau of Plant Industry. The mill was equipped with a 20 -mesh sieve (opening of $0.84 \mathrm{~mm}$ ).

\section{CONTINUOUS OIL EXTRACTION}

An extraction system, arranged as shown in the schematic diagram of figure 1, was prepared for continuous extraction of coconut oil. Dried press-cake was placed in the extraction column, which was already filled to about half with solvent. Additional material was added (press-cake and solvent) to fill the column with the aid of a rod. Enough solvent for the extraction was placed in the reservoir, and a pressure of $0.35 \mathrm{~kg} / \mathrm{cm}^{2}$ was set using $N_{2}$ from a pressure tank. The flow regulating valve was opened to the desired flow. Solvent with oil was collected in test tubes in a fraction collector. The temperature of the extraction system was kept constant by passing water at a fix flow and constant temperature through the water jacket of the column.

Experiments were carried out to study the effect of solvent flow, particle size, and temperature.

\section{BATCH-TYPE OIL EXTRACTION}

Extractions were made in glass containers placed in a constant temperature bath and provided with a stirring device. The vessel

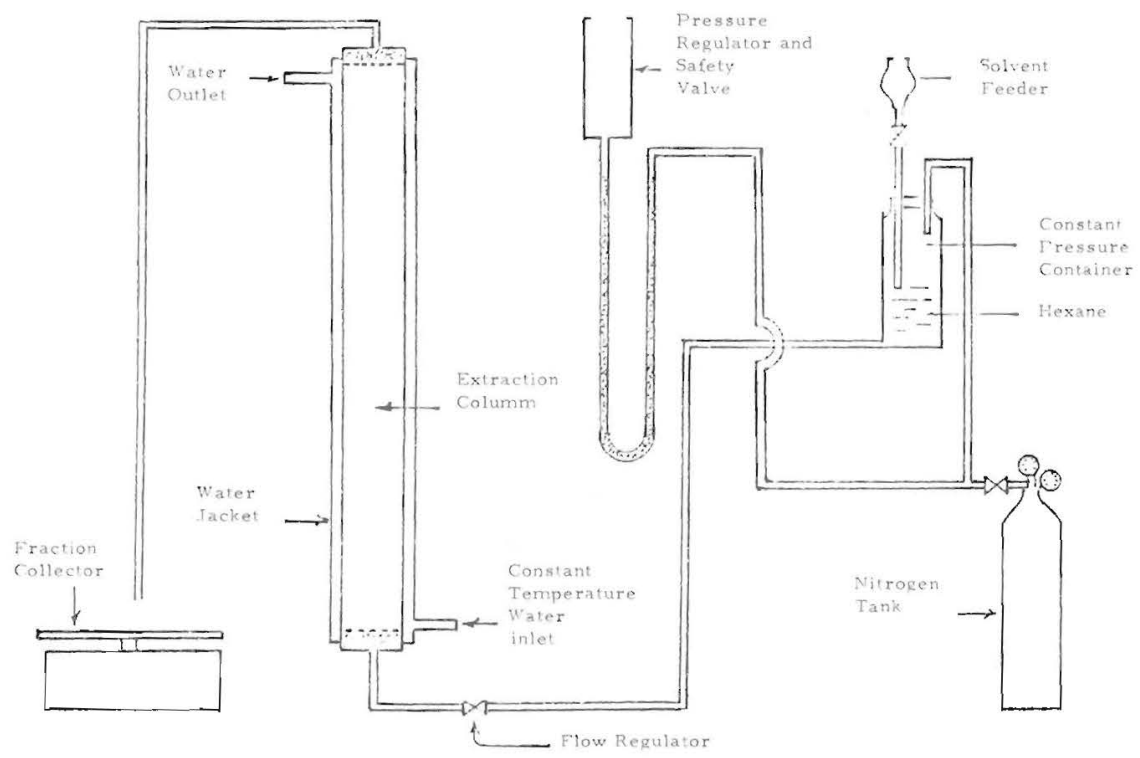

Fig. 1.-Diagrammatic representation of continunus oil extraction system used for laboratory work. 
containing the solvent was kept in the constant temperature bath in order to control the time and temperature relationship at which the extraction was conducted. The oil solvent system was separated from the solid material after each treatment by filtration through a Whatman No. 1 filter paper intended for ordinary work to retain medium-size particles. In this study $25 \mathrm{~g}$ of press-cake were placed in a predetermined amount of hexane at a preset temperature. Extraction was carried out for a given period of time with constant stirring. Oil content of press-cake was determined before and after extraction.

\section{RESULTS AND DISCUSSION}

CONTINUOUS EXTRACTION OF COCONUT OIL

Particle size composition of the coconut press-cake is presented in table 1 . The press-cake with no treatment contained about 67 to $75 \%$ particles larger than 20 mesh, while only about $5 \%$ of the milled material was in this range. Table 2 shows no difference in fat content between particles of different sizes.

TABLE 1.-Particle size classification of press-cake with no treatment and press-cake milled through a 20-mesh sieve

\begin{tabular}{|c|c|c|c|}
\hline \multirow{3}{*}{ Mesh } & \multicolumn{3}{|c|}{ Press-cake } \\
\hline & \multicolumn{2}{|c|}{ No treatment } & \multirow{2}{*}{ 20-mesh milled } \\
\hline & $\%$ & Range & \\
\hline $0-8$ & 9.5 & $8.3-10.6$ & 0 \\
\hline $8-12$ & 15.3 & - & 0 \\
\hline $12-20$ & 55.2 & $42.0-64.1$ & 4.6 \\
\hline $20-30$ & 19.1 & $16.4-21.4$ & 13.8 \\
\hline $30-40$ & 7.0 & $5.7-7.8$ & 64.7 \\
\hline $40-60$ & $3.6^{\circ}$ & $3.0-4.2$ & 16.4 \\
\hline 60 & 0.4 & $0.2-0.8$ & 0.5 \\
\hline
\end{tabular}

TABLE 2.-Results of crude fat analysis for particles of different size in the coconut press-cake

\begin{tabular}{|c|c|}
\hline Mesh & Crude fat \\
\hline & $\%$ \\
\hline \multicolumn{2}{|c|}{ First series of analyses } \\
\hline $8-12$ & 61.2 \\
\hline $12-20$ & 61.7 \\
\hline $20-30$ & 61.9 \\
\hline $30-40$ & 60.9 \\
\hline \multicolumn{2}{|c|}{ Second series of analyses } \\
\hline Unmilled press-cake & 57.8 \\
\hline $0-8$ & 58.2 \\
\hline $12-20$ & 57.8 \\
\hline $30-40$ & 59.5 \\
\hline
\end{tabular}




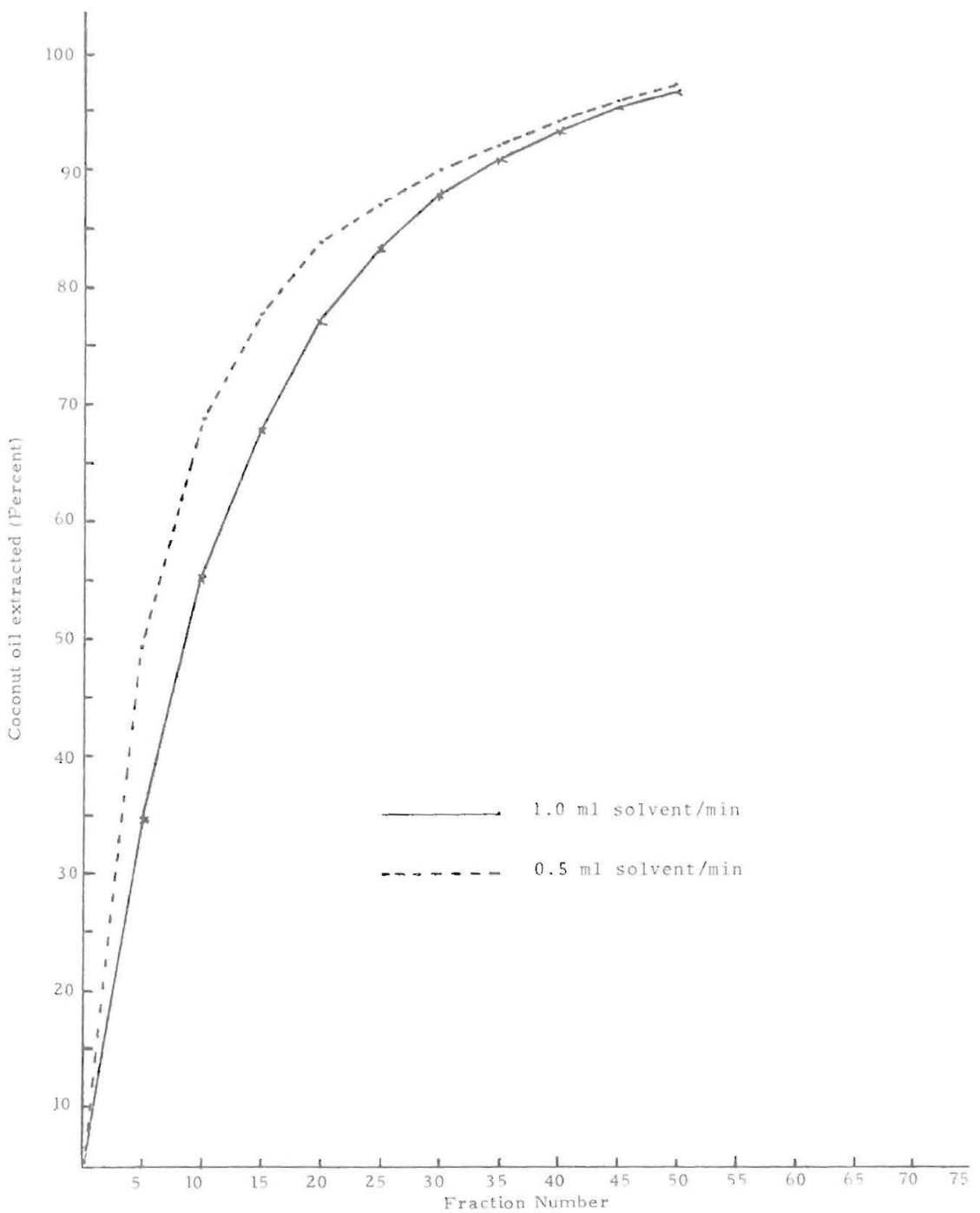

Frg. 2.-Effect of solvent flow at 0.5 and $1.0 \mathrm{ml} / \mathrm{min}$ on extraction of coconut oil from press-cake.

Results of the effect of solvent flow at 0.5 and $1.0 \mathrm{ml} / \mathrm{min}$ are shown in figure 2 and table 3 . The difference in extraction efficiency at these two levels tapers down to a negligible amount at the end of the process when $90 \%$ of the oil has been extracted. Since less solvent was used with a flow of $0.5 \mathrm{ml} / \mathrm{min}$, using the smaller flow would be more suitable.

Particle size of the press-cake affected the extraction process as shown in figure 3 and table 3 . The milled coconut press-cake gave the best results, producing an extraction of $99 \%$ in $65 \mathrm{hr}$. 
TABLE 3.-Results of experiments to determine effect of solvent flow, particle size, and temperature in the continuous extraction of coconut oil from coconut press-cake

\begin{tabular}{|c|c|c|c|c|c|c|c|c|c|}
\hline \multirow[b]{2}{*}{$\begin{array}{l}\text { Weight of coconut press- } \\
\text { cake }(\mathrm{g})\end{array}$} & \multicolumn{2}{|c|}{ Solvent flow } & \multicolumn{4}{|c|}{ Particle size } & \multicolumn{3}{|c|}{ Temperature } \\
\hline & 25.2 & 24.6 & 26.5 & 48.1 & 31.7 & 27.4 & 52.4 & 50.2 & 70.6 \\
\hline $\begin{array}{l}\text { Weight of crude fat in press- } \\
\text { cake (g) }\end{array}$ & 14.3 & 13.7 & 15.4 & 31.2 & 17.9 & 16.1 & 34.2 & 31.5 & 46.3 \\
\hline Crude fat in press-cake $(\%)$ & 56.8 & 55.7 & 58.2 & 64.9 & 56.5 & 58.6 & 65.4 & 62.8 & 65.4 \\
\hline Hexane flow $(\mathrm{ml} / \mathrm{min})$ & 0.5 & 1.0 & 0.5 & 0.5 & 0.5 & 0.5 & 1.0 & 1.0 & 1.0 \\
\hline Time per fraction (min) & 60 & 60 & 60 & 60 & 60 & 60 & 60 & 60 & 60 \\
\hline $\begin{array}{l}\text { Weight of press-cake resi- } \\
\text { due }(\mathrm{g})\end{array}$ & 10.9 & 11.1 & 11.6 & 18.1 & 12.6 & 10.8 & 18.7 & 19.3 & 25.1 \\
\hline $\begin{array}{l}\text { Oil in press-cake residue } \\
(\%)\end{array}$ & 7.9 & 8.4 & 8.0 & 0.8 & 5.8 & 4.1 & 2.8 & 1.3 & 1.0 \\
\hline Particle size (mesh) & Unmilled & Unmilled & Unmilled & $\begin{array}{l}\text { Milled } \\
20 \text { mesh }\end{array}$ & $\begin{array}{l}12-20 \\
\text { mesh }\end{array}$ & $\begin{array}{l}20-30 \\
\text { mesh }\end{array}$ & $\begin{array}{l}\text { Milled } \\
20 \text { mesh }\end{array}$ & $\begin{array}{l}\text { Milled } \\
20 \text { mesh }\end{array}$ & $\begin{array}{c}\text { Milled } \\
20 \text { mesh }\end{array}$ \\
\hline $\begin{array}{l}\text { Number of fractions col- } \\
\text { lected }\end{array}$ & 65 & 65 & 70 & 64 & 72 & 72 & 60 & 40 & 30 \\
\hline $\begin{array}{l}\text { Temperature of extraction } \\
\text { process }\end{array}$ & $20^{\circ} \mathrm{C}$ & $25^{\circ} \mathrm{C}$ & $25^{\circ} \mathrm{C}$ & $25^{\circ} \mathrm{C}$ & $30^{\circ} \mathrm{C}$ & $30^{\circ} \mathrm{C}$ & $30^{\circ} \mathrm{C}$ & $35^{\circ} \mathrm{C}$ & $45^{\circ} \mathrm{C}$ \\
\hline
\end{tabular}




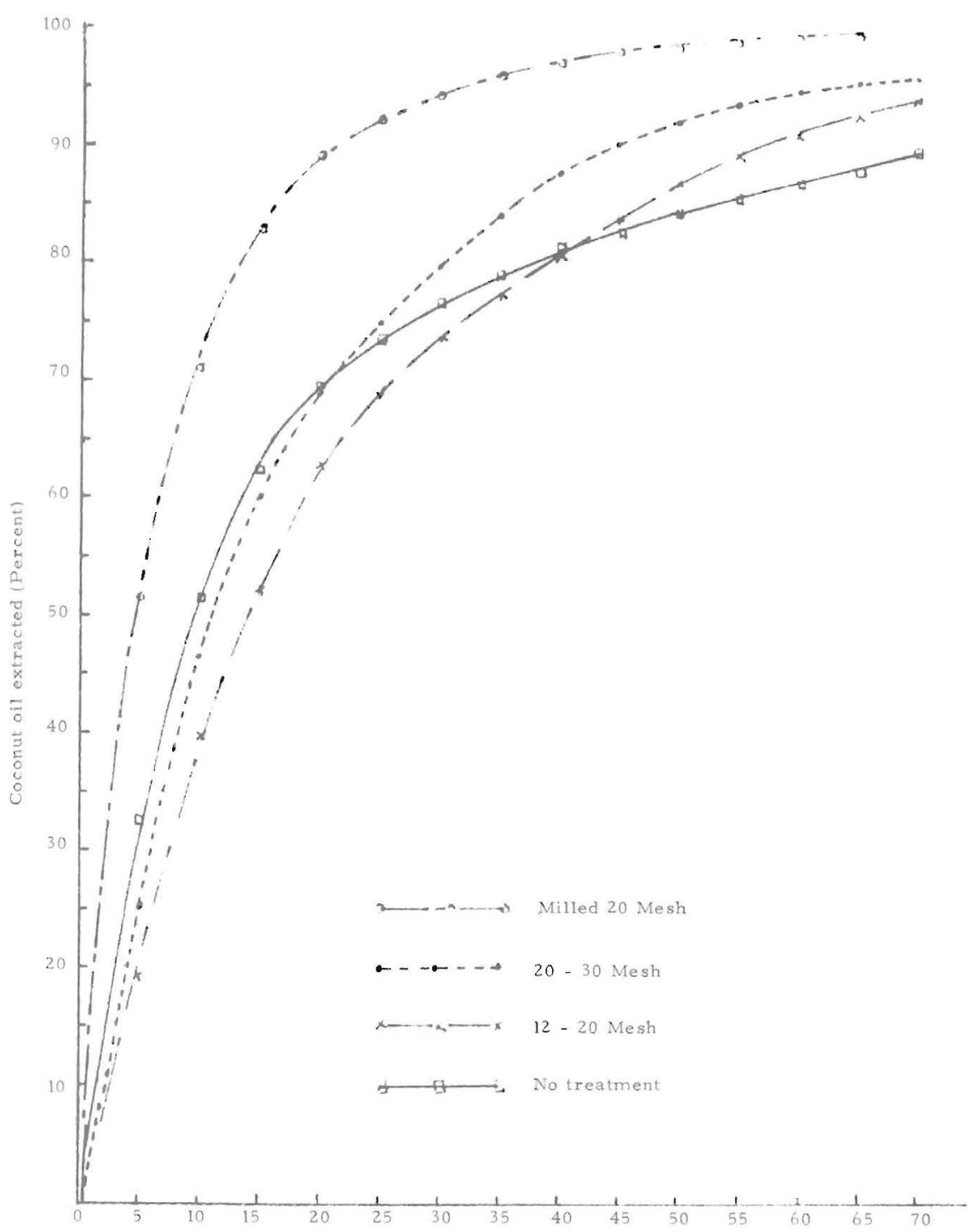

Fig. 3.-Effect of particle size of press-cake on extraction of coconut oil.

The rise of temperature in the extraction system improved the efficiency of the process as shown by the results presented in fig. 4 and table 3 . When milled coconut press-cake was extracted at $45^{\circ} \mathrm{C}$, about $99 \%$ of the oil was obtained in $30 \mathrm{hr}$. 


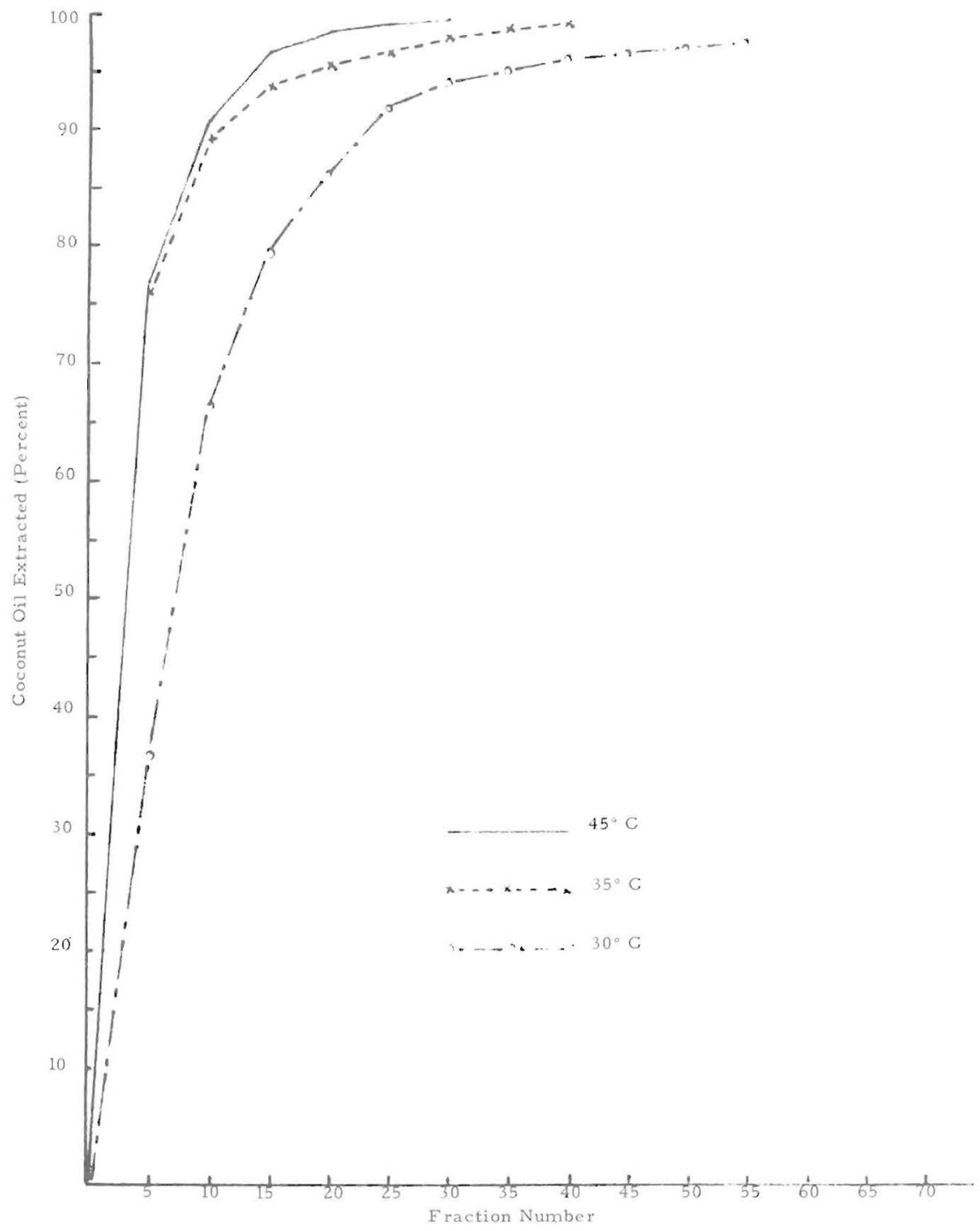

FIG. 4.-Effect of temperature on extraction of coconut oil from press-cake.

Coconut press-cake residue from the continuous coconut oil extraction process was analyzed for $\mathrm{N}, \mathrm{P}$, and $\mathrm{K}$ (table 4). Protein content of the residue increased from 8.0 to $22.2 \%^{3}$ in some of the extraction methods, thus increasing the nutritional value of this byproduct.

${ }^{3}$ Factor for converting percentage of $\mathrm{N}$ in coconuts into percentage of protein is 5.30 . 
BATCH EXTRACTION OF COCONUT OIL

Effect of temperature and particle size on batch extraction of coconut oil is shown in figure 5 and table 5 . When oil was extracted from unmilled coconut press-cake, an increase in temperature in the extraction system, from $25^{\circ}$ to $35^{\circ}$ or $45^{\circ} \mathrm{C}$ improved extraction efficiency of the system. Milled coconut press-cake (20 mesh) subjected to the extraction process showed no difference in efficiency between temperatures of $25^{\circ}, 35^{\circ}$, and

TABle 4.-Results of $N, P$, and $K$ analysis of coconut press-cake residue from continuous coconut oil extraction

\begin{tabular}{lccc}
\hline \multicolumn{1}{c}{ Description of sample } & $\mathrm{N}$ & $\mathrm{P}$ & $\mathrm{K}$ \\
\hline & & & \% \\
Original press-cake; not extracted & 1.50 & 0.22 & 0.27 \\
$25^{\circ} \mathrm{C} ; 5 \mathrm{ml} / \mathrm{min}$; not milled & 2.95 & 0.38 & 0.49 \\
$25^{\circ} \mathrm{C} ; 1.0 \mathrm{ml} / \mathrm{min}$; not milled & 2.95 & 0.40 & 0.49 \\
$25^{\circ} \mathrm{C} ; 0.5 \mathrm{ml} / \mathrm{min} ; 12-20$ mesh & 2.84 & 0.58 & 0.65 \\
$25^{\circ} \mathrm{C} ; 0.5 \mathrm{ml} / \mathrm{min} ; 20-30$ mesh & 3.36 & 0.41 & 0.55 \\
$25^{\circ} \mathrm{C} ; 0.5 \mathrm{ml} / \mathrm{min} ;$ milled, 20 mesh & 4.12 & 0.51 & 0.69 \\
$45^{\circ} \mathrm{C} ; 0.5 \mathrm{ml} / \mathrm{min}$; milled, 20 mesh & 4.18 & 0.54 & 0.72 \\
$45^{\circ} \mathrm{C} ; 1.0 \mathrm{ml} / \mathrm{min} ;$ milled, 20 mesh & 4.12 & 0.54 & 0.72 \\
$35^{\circ} \mathrm{C} ; 1.0 \mathrm{ml} / \mathrm{min} ;$ milled, 20 mesh & 3.82 & 0.45 & 0.84 \\
$45^{\circ} \mathrm{C} ; 1.0 \mathrm{ml} / \mathrm{min}$; milled, 20 mesh & 3.68 & 0.43 & 0.57 \\
$45^{\circ} \mathrm{C} ; 1.0 \mathrm{ml} / \mathrm{min}$; milled, 20 mesh & 3.62 & 0.44 & 0.84 \\
Average for extracted press-cake & 3.56 & 0.47 & 0.56 \\
\hline
\end{tabular}

TABLE 5.-Influence of temperature and particle size on percentage of oil extraction in the batch extraction process ${ }^{1}$

\begin{tabular}{cccc}
\hline \multirow{2}{*}{ Fraction } & \multicolumn{3}{c}{ Total oil extracted } \\
\cline { 2 - 4 } & $25^{\circ} \mathrm{C}$ & $35^{\circ} \mathrm{C}$ & $45^{\circ} \mathrm{C}$ \\
\hline No. & \multicolumn{3}{c}{$\%$} \\
& & Unmilled press-cake & \\
1 & 64.8 & 74.8 & 73.9 \\
2 & 84.7 & 91.0 & 90.5 \\
3 & 90.3 & 95.9 & 95.5 \\
1 & 93.7 & 98.1 & 98.1 \\
5 & 95.6 & 99.4 & 99.9 \\
& & 86.2 & 84.5 \\
1 & 84.0 & 96.9 & 95.6 \\
3 & 95.7 & 99.1 & 98.9 \\
4 & 97.9 & 99.9 & 99.5 \\
5 & 99.2 & & 99.8 \\
\hline
\end{tabular}

${ }^{1}$ Coconut oil extracted from press-cake, which was unmilled or milled through a 20 -mesh sieve, using $200 \mathrm{ml}$ hexane, $15 \mathrm{~min}$ stirring time, and temperatures of $25^{\circ}, 35^{\circ}$, and $45^{\circ} \mathrm{C}$. 


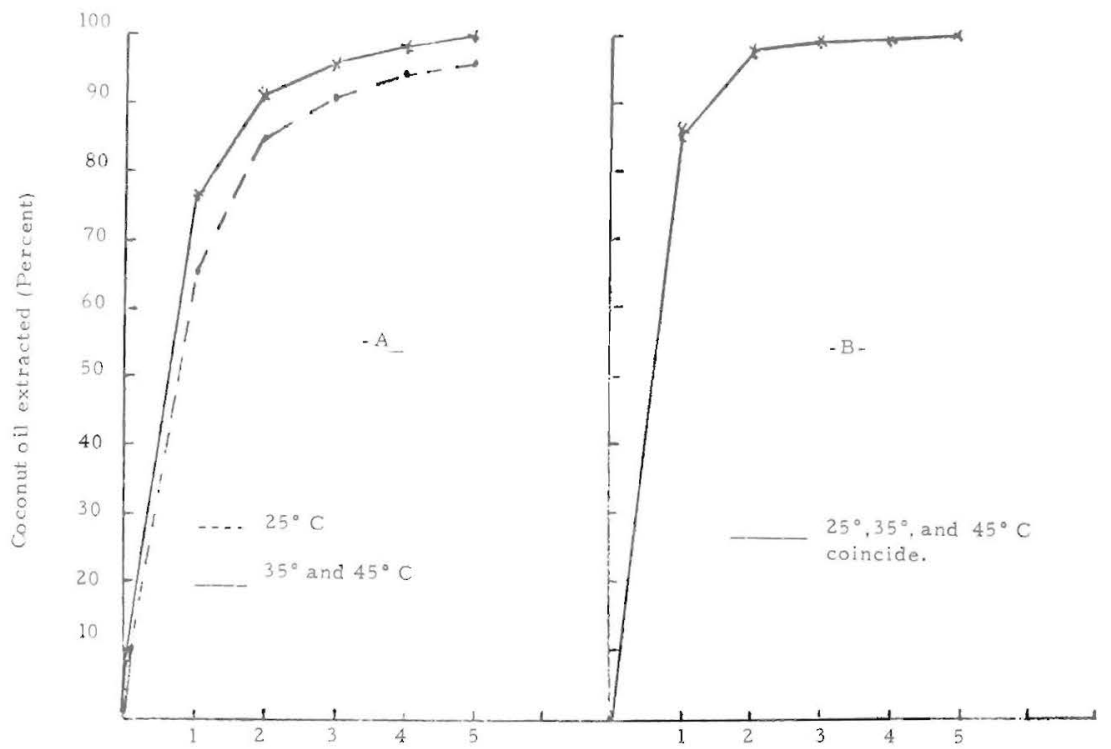

FIG. 5.-Batch extraction of coconut oil from press-cake. A, Unmilled press-cake, $200 \mathrm{ml}$ hexane/batch, 15 min stirring time, and temperature of $25^{\circ}, 35^{\circ}$, and $45^{\circ} \mathrm{C} ; \mathrm{B}, 20$-mesh milled press-cake, $200 \mathrm{ml}$ hexane/batch, $15 \mathrm{~min}$ stirring time, and temperature $25^{\circ}, 35^{\circ}$, and $45^{\circ} \mathrm{C}$.

TABLE 6.-Influence of quantity of solvent on percentage of oil extracted in the batch process from 20-mesh milled press-cake

\begin{tabular}{cccc}
\hline \multirow{2}{*}{ Fraction } & \multicolumn{3}{c}{ Amount of oil extracted $^{1}$} \\
\cline { 2 - 4 } & $50 \mathrm{ml}$ hexane & $100 \mathrm{ml}$ hexane & 150 ml hexane \\
\hline No. & $\%$ & $\%$ & $\%$ \\
1 & 58.1 & 75.1 & 78.3 \\
2 & 83.0 & 96.4 & 96.0 \\
3 & 99.5 & 99.1 & 99.0 \\
4 & 91.7 & 99.4 & 99.3 \\
5 & 92.4 & 99.9 & 99.6 \\
\hline
\end{tabular}

${ }^{1}$ Stirring time was $5 \mathrm{~min}$, and temperature was $25^{\circ} \mathrm{C}$.

$45^{\circ} \mathrm{C}$ in the system (fig. 5). Particle size had a definite effect on extraction efficiency. Milled coconut press-cake (20 mesh) resulted in more complete and faster extraction than unmilled press-cake (fig. 5).

The amount of solvent used in the extraction also affected the process. A ratio of $2: 1(\mathrm{ml}: \mathrm{g})$ did not provide for as efficient an extraction as a $4: 1$ ratio. However, increasing the ratio to $6: 1$ did not improve the extraction (fig. 6 and table 6). 
Length of extraction period (stirring time) did not affect extraction efficiency to a great extent. The small difference in extraction efficiency is shown in fig. 6 and table 7.

Results obtained in the experiments with the batch extraction method suggest the possibility of using this system in a commercial installation. Five interconnected tanks could be worked to provide an extraction of about $99 \%$ of the total oil present in the press-cake.

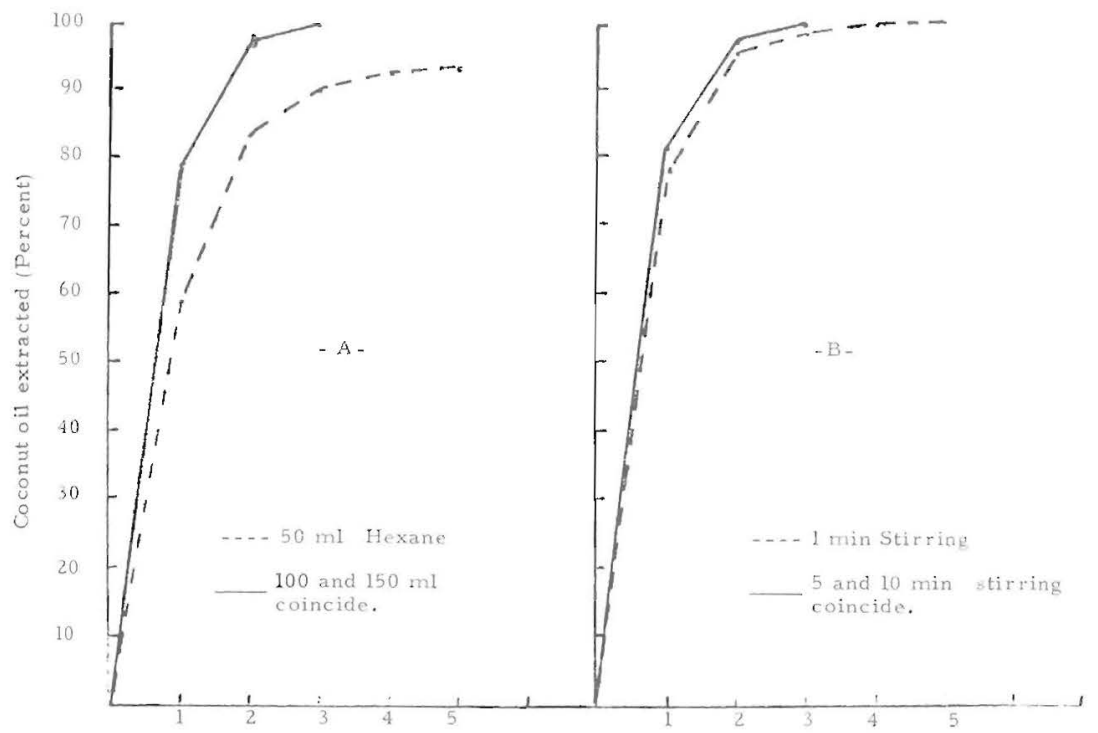

FiG. 6.-Batch extraction of coconut oil from press-cake. A, 20-mesh milled press-cake, $5 \mathrm{~min}$ stirring time, temperature of $25^{\circ} \mathrm{C}$, and 50,100 , and $150 \mathrm{ml}$ hexane/batch; $\mathrm{B}$, 20-mesh milled press-cake, temperature of $25^{\circ} \mathrm{C}, 100 \mathrm{ml}$ hexane/batch, and 1,5 , and 10 min stirring time.

TABLE 7.-Influence of stirring time on percentage of oil extracted in the batch-extraction process of coconut oil from 20-mesh milled press-cake

\begin{tabular}{cccc}
\hline \multirow{2}{*}{ Fraction } & \multicolumn{3}{c}{ Stirring time } \\
\cline { 2 - 4 } & $1 \mathrm{~min}$ & $5 \mathrm{~min}$ & $10 \mathrm{~min}$ \\
\hline No. & $\%$ & $\%$ \\
1 & 77.7 & 80.9 & 79.2 \\
2 & 95.0 & 96.1 & 96.4 \\
3 & 98.3 & 99.1 & 98.8 \\
4 & 99.1 & 99.7 & 93.3 \\
5 & 99.4 & 99.9 & 99.8 \\
\hline
\end{tabular}

${ }^{1}$ Temperature was $25^{\circ} \mathrm{C}$ and $100 \mathrm{ml}$ hexane was used. 


\section{RESUMEN}

Existe un buen potencial para la extracción de aceite de coco de la cachipa, residuo resultante de la extracción de la leche de coco, dado al alto precio que tienen hoy día los aceites vegetales para consumo humano. En el proceso industrial para la preparación de leche de coco la cachipa representa approximadamente 40 por 100 de la pulpa. Esta tiene cerca de 50 por 100 de agua y 48 por 100 de grasa (base seca).

Al determinar las características de la cachipa se encontró que d el 67 al 75 por 100 de las partículas no pasaban por el cedazo número 20. En los experimentos de extracción continua, usando hexano como solvente, se encontró que el tamaño de las partículas fue un factor determinante en la eficiencia del proceso. Por esta razón se decidió pasar la cachipa por un molino de martillos equipado con un cedazo número 20.

En las pruebas realizadas para estudiar el flujo del solvente, el tamaño de las partfculas y la temperatura del sistema se encontró que, en el caso de un flujo de 0.5 y $1.0 \mathrm{ml} . / \mathrm{min}$., el de $0.5 \mathrm{ml}$. dió mejores resultados al inicio de la extracción, pero que esta diferencia tendía a nivelarse al final del proceso. En cuanto al tamaño de las partículas, se encontró que con la cachipa molida, usando un cedazo número 20 , se logró una extracción de 99 por 100 en 65 horas y que la temperatura aumentó la rapidez de extracción, ya que al subirla a $45^{\circ} \mathrm{C}$. se obtuvo una extracción de 99 por 100 en 30 horas.

En los estudios de extracción por lote se encontró que el efecto de la temperatura fue notable cuando se usó cachipa sin moler, pero que cuando se usó cachipa molida (cedazo 20) no hubo diferencia. Se encontró además que, la relación de cachipa a solvente debía ser de 1 gramo de cachipa para $4 \mathrm{ml}$. de solvente.

En el sistema de extracción por lotes se estudió el efecto del tiempo de retención (tiempo que la cachipa estaba inmersa en el solvente). Se encontró que con 1 min. de inmersión no se lograron los mismos resultados que cuando ésta fue de 5 ó 10 minutos. Con 5 minutos de inmersión la extracción alcanzó un máximo en tres extracciones.

\section{LITERATURE CITED}

1. Cancel, L. E., Rivera-Ortíz, J. M., and Santos-Sánchez, M., Effect of the amount of water on the extraction of coconut milk at two temperature ranges, J. Agr. Univ. P. R. 55(2): 167-73, 1971.

2. —- Rosario-Hernández, J. A., and R. de Hernández, E., Extraction of coconut milk by continuous screw-press, J. Agr. Univ. P. R. 58(3): 322-9, 1974.

3. - Rivera-Ortí, J. M., and R. de Hernández, E., Coconut milk extraction from frozen pulp. J. Agr. Univ. P. R. 60(3): 271-80, 1976.

4. Jamieson, G. S., Vegetable fats and oils, 2nd ed, Reinhold Publishing Corp., New York, pp. $146-7,1943$. 
5. Smith, A. K., and Circle, S. J., Soybeans: chemistry and technology, Vol, I, The Avi Publishing Co., Inc., Westport, Conn., pp. 144-5, 1972.

6. Parker, M. E., Harvey, E. H., and Stateler, E. S., Elements of food engineering, Vol. 2, Reinhold Publishing Corp., New York, pp. 175-7, 1954.

7. Charm, S. E., The fundamentals of food engineering, The Avi Publishing Co., Inc., Westport, Conn., pp. 417-23, 1963.

8. Becker, K. W., Processing of oil seeds to meal and protein flakes, J. Amer. Oil Chem. Soc. 48(6): 299-304, 1971. 